WALDEMAR SPALLEK

University of Wrocław, Institute of Geography and Regional Development

Department of Geoinformatics and Cartography

Wrocław, Poland

waldemar.spallek@uwr.edu.pl

\title{
Evolution of longitude description system. Example of Polish school geographical atlases (1771-2012)
}

\begin{abstract}
The evolution of the mathematical foundations of maps in school geographical atlases, especially in 19th and 20th century, was one of the elements of the perception of progress in cartography by the didactics of geography. The biggest changes, ongoing also today, concerned cartographic projections used to maps design.

The evolution of the geographical coordinate system is a part of this process and the basis of the theory of cartographic projections. In the paper there are described changes concerning the location of the Prime Meridian and the method of the description of longitude - elements necessary for the construction of the grid of meridians and parallels. These changes are presented on the basis of analysis of 665 atlases, what means all editions of Polish school geographical atlases between 1771 and 2012 identified by the author.

The evolution of the mathematical foundations of maps in Polish school atlases over more than two centuries is an example of assimilation of the newest trends and scientific researches that takes place between science and education.
\end{abstract}

Keywords: school atlases, geographical coordinate system, the description of longitude, Prime Meridian

\section{Introduction}

The geographical latitude is naturally measured from the longest parallel, or the equator, towards the poles. Moreover, during the spring and autumn equinoxes the height of the sun above the horizon complements the angle of geographical latitude to the right angle. In the case of geographical longitude, the initial meridian and the way of recording are the conditional issues. In the second century AD, Ptolemy in his work "Geography" used the Ferro Meridian to determine the geographical longitude of the objects he listed. That meridian crossed the westernmost tip of the known lands, the island of Ferro (Spanish: El Hierro) in the Canary Archipelago. Due to that fact, the geographical longitudes of all objects were measured eastwards from the initial meridian. The printing of the Ptolemy's work in the fifteenth century had contributed to the dissemination of the Ferro Meridian on maps. In the modern era, when, along with the great geographical discoveries, the lands known to Europeans covered the whole Earth, the geographical longitude was still measured eastwards from the initial meridian (usually Ferro), assigning its values from $0^{\circ}$ to $360^{\circ}$. All great atlases of the world from the 16 th century to the 18 th century contained the maps with such a record of geographical longitude.

On the maps from the Polish school atlases, in the course of over 240 years of their history, in principle, two initial meridians were used to determine the geographical longitude: Ferro and Greenwich. Occasionally, in only eight atlases and only on some maps, some other meridians appeared: the Paris Meridian was used in six atlases - in three atlases by J. Kośmiński from 1833-1840 [15 and 16] ${ }^{1}$, in the two-part atlas by I. Dzierżyński from the years of 1918 and 1919 [7 and 8] and in two editions of the large atlas of the world by J.M. Bazewicz from

\footnotetext{
${ }^{1}$ Numbers in square brackets refer to the item numbers from the list of atlases at the end of the article.
} 
the years of 1918 and 1921 [6], but in one of them, Podreczny atlas geograficzny (Geographical hand atlas), 1908 [20], the Warsaw Meridian was used.

\section{The dominance of two meridians: Ferro and Paris}

The Paris Meridian was established in 1667 at the site of the future astronomical observatory in Paris, which was completed in 1671. Although the Ferro Meridian had been coming out from the times of antiquity, in 1725 the commission, presided over by Guillaume Delisle, assumed that the Ferro Meridian was conditionally located $20^{\circ}$ west from the Paris Meridian. In practice, it turned out that the difference was slightly larger (according to the later measurements it was set at $20^{\circ} 23^{\prime} 9^{\prime \prime}$ ), but on the maps an easier twenty-degree angular distance between those two meridians was used for calculations. As a result, the Ferro Meridian became a camouflaged Paris Meridian - "The meridian of Paris disguised", as it was stated by the French delegate to the Meridional Conference J. Janssen (International conference... 1884, p. 57).

Both meridians had been widely used on the maps for over 200 years. The Anglo-Saxon countries that never adopted the "French" Ferro, using their own Greenwich Meridian (International conference... 1884; M. Sirko 1999, www.Paris 2015), were the exceptions. The hemispheres in the transverse projection, depicting the eastern and western hemispheres, were the basic world's map forms up to the end of the 19th century. The earth was divided into the hemispheres along the Ferro Meridian and its anti-meridian. Along with the introduction of the Greenwich Meridian, the meridian of $20^{\circ} \mathrm{W}$ and $160^{\circ} \mathrm{E}$ began to determine the boundaries between two hemispheres, i.e. paraphrasing J. Janssen, who was quoted above, the camouflaged meridian of Ferro and its anti-meridian.

Since the publication of the first Polish school geographical atlas in 1771, compiled by D. Szybiński [24], until 1875, that is until the end of publication of the first series of atlases by B. Kozenn [17], only the Ferro Meridian had been substantially used to determine the geographical longitude in the Polish school atlases. Only in his historic-geographical atlas J. Koś- miński [15] applied a double longitude notation: according to the Paris Meridian (on the north map frame) and the Ferro Meridian (on the south map frame), which was easy, on the condition that the difference between those two meridians was $20^{\circ}$, and did not require to draw the additional meridional lines. On two historical maps: Grecja starożytna i Państwo Rzymskie część wschodnia (Ancient Greece and Roman State, the eastern part), J. Kośmiński made quite a serious mistake. On the top frame, where the longitude values should be found according to the Paris Meridian, the distances from Ferro were given. On the bottom frame, in accordance with the principle of a twenty-degree difference between the meridians of Ferro and Paris, the numerical values were $20^{\circ}$ higher. As a result, on the bottom frame you could find the geographical latitudes for the Balkan peninsula with values of $60^{\circ}-65^{\circ}$, which were as incorrect for one notation, as for another one. The last atlases, in which the longitude description according to the Ferro Meridian was exclusively applied, were Atlas przyrodniczo-geograficzny... (Natural and geographical atlas...) by O. Schneider from the year of 1900 [22] and Szkolny atlas statystyczny Polski (School statistical atlas of Poland) by I. Weinfeld, E. Szturm de Sztrem and J. Piekałkiewicz from the year of 1925 [25], and therefore published more than 40 years after the International Meridional Conference.

\section{The International Meridional Conference, 1884}

In the mid-nineteenth century, along with the development of railways and sea shipping, the lack of universal system of determining the geographical longitude was getting an increasingly serious problem. The size of geographical longitude was directly proportional to the time difference between two places on the Earth, but the measurement of that difference required the standardization of time. For this purpose, on the 1st of October, 1884, the delegates from 25 then independent states met in Washington at the International Meridional Conference (including, among others, the Kingdom of Hawaii and the United Kingdom of Sweden and Norway). The final act contained seven points, which were voted on the $22 \mathrm{nd}$ of October, 1884. In the first of them, adopted 
unanimously, the need to adopt one standard meridian for longitude measurements around the world was approved. In the second point it was proposed to the delegates to make the meridian passing through the Greenwich $\mathrm{Ob}$ servatory to be the Prime Meridian. That postulate was supported by 22 countries, with one vote of opposition (Dominican Republic) and two abstentions (France and Brazil). In the third point, it was decided that the geographical longitude from the Greenwich Meridian would be count in two directions to $180^{\circ}$. In addition, it was determined that the eastern longitude would be marked as positive and the western one as negative. Interestingly, the proposals contained in the third point had caused the greatest controversy. It was supported by 14 delegations, five countries were against (Italy, Sweden, the Netherlands, Switzerland and Spain) and six abstained (the Austria-Hungary, Germany, Brazil, Dominican Republic, France and Turkey). The remaining four points regarding the standardization of time measurement were adopted without major objections (International conference... 1884).

The choice of the Greenwich Meridian was followed by several important reasons, among which economic and political factors played a significant role. As it was postulated during the Meridional Conference, it was necessary to choose the meridian, which was already widespread, the introduction of which would result in the lowest costs associated with the development of new sea charts. The meridian passing through the Greenwich Observatory, which was founded in 1675, was for the first time designated in the early eighteenth century. It did not have such a long tradition as other meridians, which were used before: Ferro (= Paris), Rome, Florence, Cadiz or Toledo, but it had one significant advantage - it was widely used in sea shipping. Until the development of effective chronometers, the method of lunar distance invented by Nevil Maskelyne (1732-1811) had been using for measuring the geographical longitude, and it required to use the special astronomical tables. For that purpose, from 1766, Nevil Maskelyne, who was appointed the Royal Astronomer in 1765, began to publish "The Nautical Almanac and Astronomical Ephemeris", containing the distances of the Moon from the Sun and the stars measured against the Greenwich Meridian. The naviga- tors using "Almanac" also began to determine the location of their ships from that meridian. That meridian was also left in the French translation of Maskelyne' tables, even though the Paris Meridian was used on the others. In the early nineteenth century, the method of measuring the geographical longitude using a chronometer gained the advantage, but sailors, in order to control their clocks, continued to use "Almanac" and the method of lunar distances, calculating the longitude from Greenwich (D. Sobel 1998). In the second half of the 19th century, the navigation maps with the Greenwich Prime Meridian covered all the navigable waters of the world, and they were used on $65 \%$ of ships (table 1). Moreover, a year before the Meridional Conference, on the 18th

Table 1. Number and total tonnage of vessels using the navigational charts with the most commonly used prime meridians in 1879

\begin{tabular}{|l|r|r|r|r|}
\hline \multirow{2}{*}{$\begin{array}{c}\text { Name of the } \\
\text { Prime Meridian }\end{array}$} & \multicolumn{2}{|c|}{ Vessels } & \multicolumn{2}{c|}{ Percentage } \\
\cline { 2 - 5 } & number & tonnage & vessels & tonnage \\
\hline Greenwich & 37663 & 14600972 & 65,0 & 72,0 \\
\hline Paris & 5914 & 1735083 & 10,0 & 8,0 \\
\hline Cadiz & 2468 & 666602 & 5,0 & 3,0 \\
\hline Naples & 2263 & 715448 & 4,0 & 4,0 \\
\hline Christiania (Oslo) & 2128 & 695988 & 4,0 & 3,0 \\
\hline Ferro & 1497 & 567682 & 2,0 & 3,0 \\
\hline Pulkovo & 987 & 298641 & 1,5 & 1,5 \\
\hline Stockholm & 717 & 154180 & 1,5 & 1,0 \\
\hline Lisbon & 491 & 164000 & 1,0 & 1,0 \\
\hline Copenhagen & 435 & 81888 & 1,0 & 0,5 \\
\hline Rio de Janeiro & 253 & 97040 & 0,5 & 0,5 \\
\hline others & 2881 & 534569 & 4,5 & 2,5 \\
\hline in total & 57697 & 20312093 & 100,0 & 100,0 \\
\hline
\end{tabular}

Source: International conference... 1884, p. 77.

of November, 1883, the time zones based on the Greenwich Meridian were accepted on the railway lines in the United States and Canada (International conference... 1884; www.Greenwich 2015; www.Greenwich_meridian 2015). According to Arno Peters (M. Monmonier 2004), the most important premise for establishing the Greenwich Meridian as the initial one for longitude measurement was the power position of Great Britain, which at the end of the 19th century dominated on the seas, had the largest colonial empire and was the world's 
largest economic power. In the nineties of the 19th century, it was overtaken by the United States, intensively developing after the Civil War (A. Leszczyński 2015).

\section{Transitional period and final admission of the Greenwich Meridian}

The postulates regarding Prime Meridian accepted during the International Meridional Conference were supported by three partitioning countries (at that time the Polish lands were divided between the Austria-Hungary, Germany and Russia), which was also reflected in the school atlases published at the time (figs. 1 and 2). For the first time, the description of geographical longitude from the Greenwich Meridian was introduced in the year of 1879 on a part of maps in the first edition of new atlas for the secondary schools by B. Kozenn [18]. The edition of this atlas can be considered as the beginning of the transitional period, in which the Ferro Meridian has gradually been replaced by the Greenwich Meridian. Another breakthrough was the first circulation of the second edition of the B. Kozenn's atlas for the secondary schools in 1898 [19], in which all geographical maps were given only from the Greenwich Meridian. The symbolic end of that transitional period was a publication of the last issue of the W. Haardt's atlas in its Polish version in 1930 [14], in which maps for the last time were placed with a longitude record measured from the Ferro Meridian, along with the maps in the Greenwich system.

Different solutions, regarding the standard meridian, appeared in atlases during the transitional period. While E. Romer in his first school atlas [21] as well as in his next works accepted the Greenwich Meridian, in the atlases of other publishing houses we are dealing with a great deal of freedom, if not a mess. That situation appeared due to the economic reasons (e.g. the reluctance to bear the costs of drawing the new maps with a graticule lines consistent with the Greenwich Meridian), as well as due to the business causes (e.g. following the wishes of customers who were used to the previous meridian called Ferro). In the first edition of the new atlas by B. Kozenn (at least 12 outlays appeared in the years

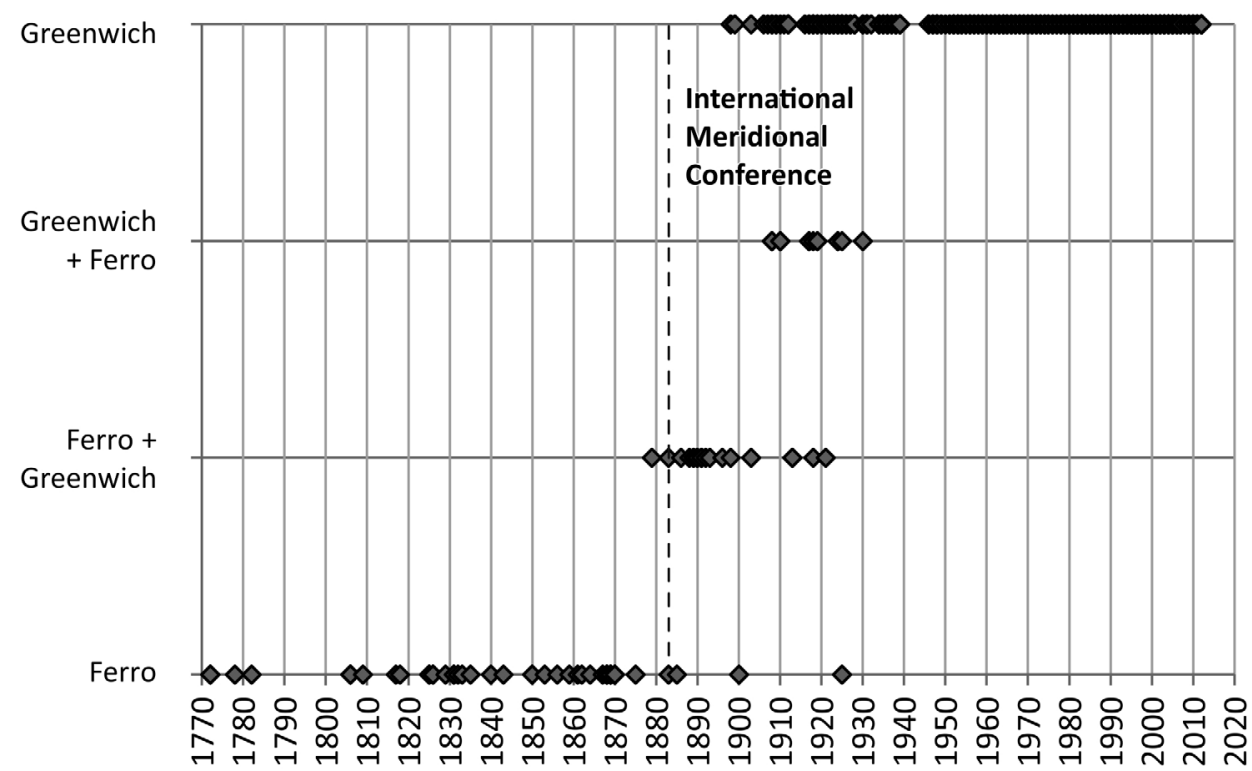

Fig. 1. The publications of the Polish school atlases according to the Prime Meridian used in them (the only case of using the Warsaw Meridian, 1908, is not taken into account). The Paris Meridian is included in the Ferro longitude system. If two meridians are indicated, one of them, predominating in the atlas, is the first one to be given 


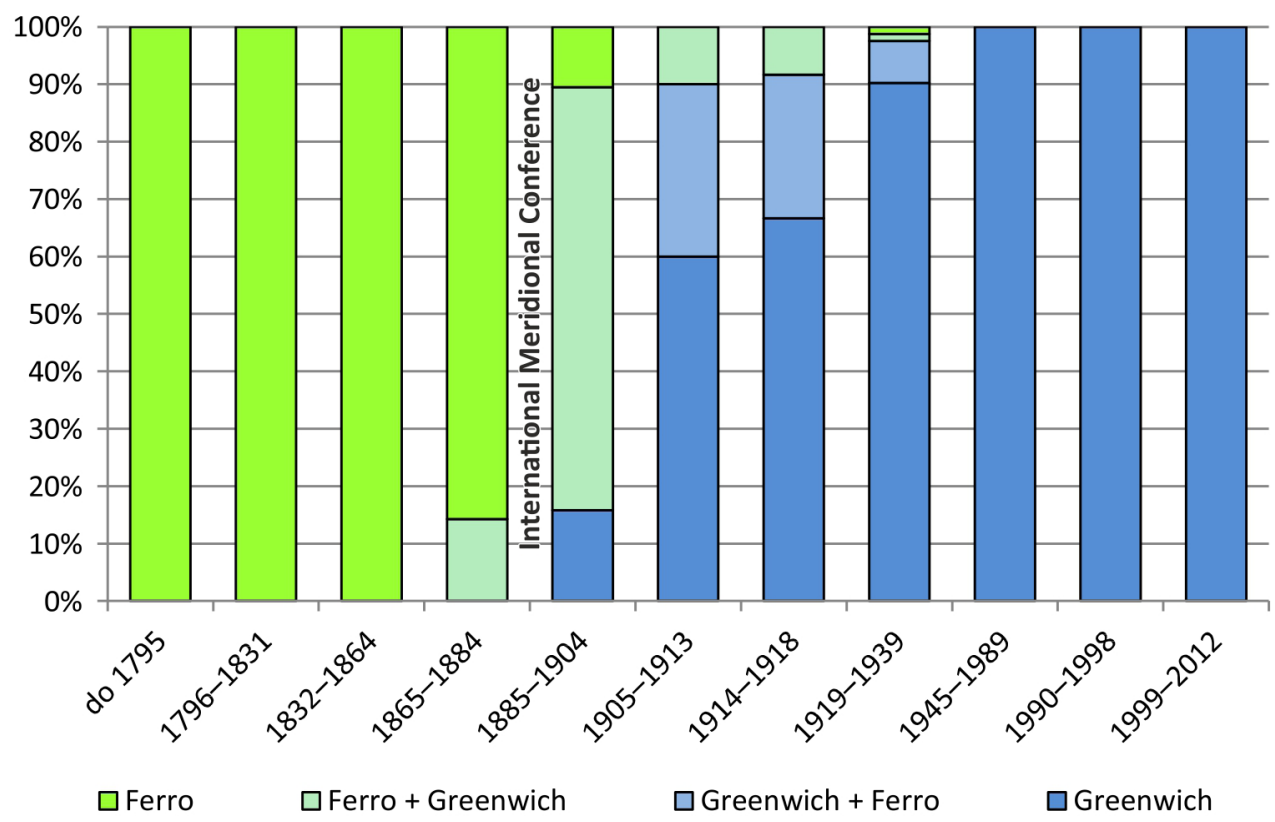

Fig. 2. The structure of atlases in the particular historical periods according to the Prime Meridian used on the maps (one case of using the Warsaw Meridian, 1908, is not included). The Paris Meridian is included into the Ferro longitude system. If two meridians are indicated, one that predominates in the atlas is the first one to be given

1879-1904 [18]) some of the maps have the longitude described in the Ferro system (the most of them), part in Greenwich, and some in both systems. This is how the general geographical and political maps of some continents (Africa, America and Australia) were carried out, on which cartographical grids were drawn in line with the Greenwich Meridian. This is how the longitude was described, but additionally, on a step frame, the longitude values were measured from the Ferro Meridian. On the other hand, the planiglobes (the spheres projected onto the flat planes), and the general geographical and political maps of Asia had a graticule and a description of meridians compatible only with the Greenwich system. On a planiglob, the Greenwich Meridian was thickened, and the intersection of the Ferro Meridian and equator was marked with a line and described: $0^{\circ}$ od Ferro ( $0^{\circ}$ from Ferro) over the equator and $-17^{\circ} 39^{\prime} 51^{\prime \prime}$ od Greenw. $\left(-17^{\circ} 39^{\prime} 51^{\prime \prime}\right.$ from Greenwich) under the equator. Other maps referred the longitude and graticule lines to the Ferro Meridian. On the maps in the atlases by B. Gustawicz [9, 10, 11 and 12] a similar procedure was used as in the atlas by B. Kozenn. The Greenwich Meridian was adopted, but the longitudes measured from the Ferro Meridian (fig. 3) were additionally described on the parts of maps on the step frame.

In the case of some atlases, one could get the impression that the adoption of that or other standard meridian on the maps was completely accidental and often resulted from the ignorance of an author who compiled (copied) the maps from the various sources. As a result, in some atlases one could find maps with three systems for determining the longitude. An example was Podręczny atlas geograficzny (Geographical hand atlas) [20] issued around the year of 1908 by the publishers of Joint Stock Company S. Orgelbrand and Sons. On the most maps the Greenwich Meridian was used, with the exception of two European maps, where the longitude was marked from the Ferro Meridian. Moreover, on Mapa dziesięciu guberni Królestwa Polskiego (Map of ten 


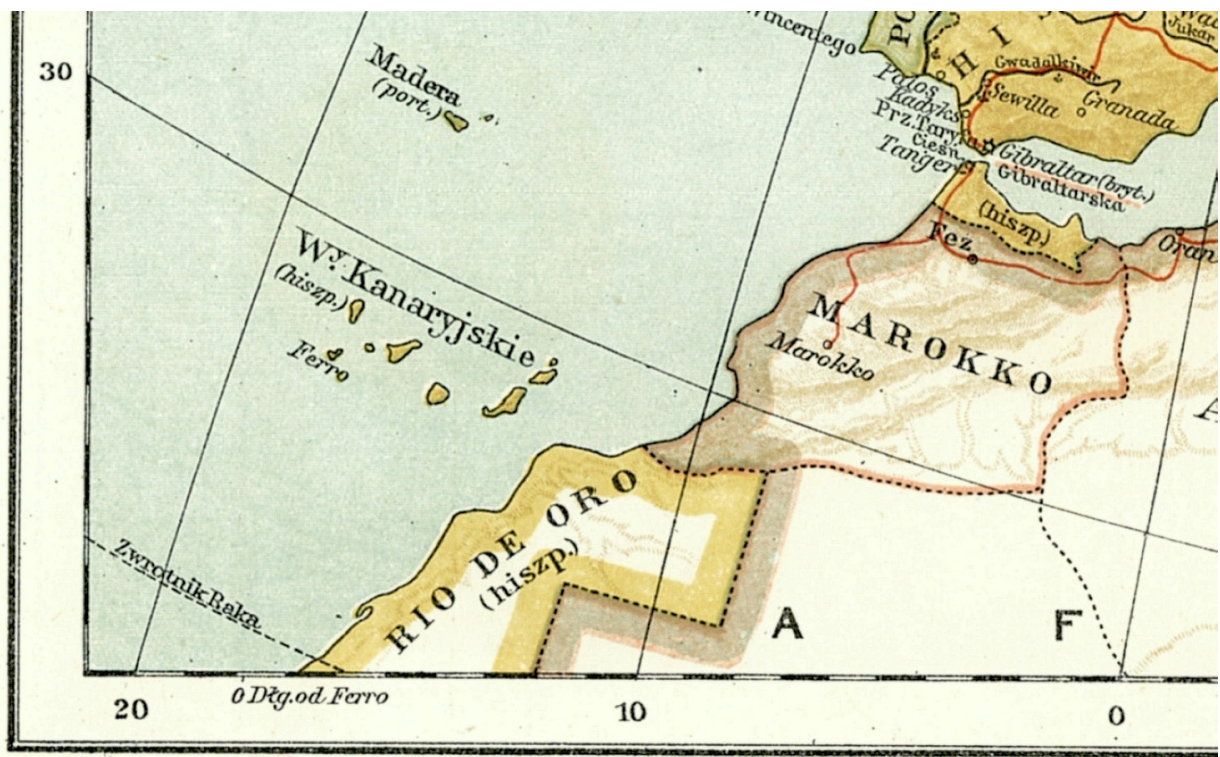

Opracowal' Br. Gustawicz.

Fig. 3. A part of the map of Europe with the description of the graticule lines in the Greenwich system and the location of the Ferro Meridian from the Atlas geograficzny dla szkót średnich (Geographical atlas for secondary schools) by B. Gustawicz, 1925 [12], pp. 7-8

governorates of the Kingdom of Poland) (fig. 4), the Prime Meridian was the Warsaw Meridian - the only example of using that meridian in a Polish school atlas. In turn, in the two-part Atlas do geografji Polski (Atlas for the geography of Poland) by I. Dzierżyński, published in 1918 and 1919 [7 and 8], in general, few maps had the graticule lines. In the first part, out of 48 maps, the only seven, showing hydrographical issues, had the graticule lines. Interestingly, regardless of a subject of a map, on three of them (the bathymetries of the Baltic Sea, the Odra basin and the Rzeki wschodnie (Eastern rivers) Greenwich was accepted as the Prime Meridian, on the next two (the Vistula basin and the Lakeland of Livonia) it was the Ferro Meridian, and on the other next two Jeziora Suwalskie i Mazurskie and Jeziora Kujawskie (Suwałki and Masuria Lakes and Kujawy Lakes) - the Paris Meridian.

\section{Changes in the description of geographical longitude on the maps}

In the majority of the Polish school atlases published until 1875 (i.e. until the end of publi- cation of the first series of atlas by B. Kozenn [17]), the description of geographical longitude to the east from the Ferro Meridian up to $360^{\circ}$ was used on the maps. The atlases by W.B. Korn, issued in 1806-1831 [1, 2, 3, 4 and 5], and J. Kośmiński from 1833-1840 [15 and 16] (figs. 5 and 6 ), in which the notation of longitude to $180^{\circ}$ was used eastwards, and from the Ferro Meridian or the Paris Meridian westwards, were exceptional. The postulate regarding the method of measuring the longitude up to $180^{\circ}$ east and west from the Prime Meridian accepted by the International Meridional Conference was supported by Russia, but the Austria-Hungary and Germany abstained from voting. Nevertheless, already in 1879, when the first edition of new atlas for the secondary schools appeared by B. Kozenn [18], that way of recording the geographical longitude began to dominate on the maps of the Polish school atlases. Two editions of the Atlas geograficzny duży... (Large geographical atlas...) by J. Bazewicz from around 1918 and 1921 [6] and the atlas for the folk schools by W. Haardt (eight editions and circulations in the years of 1883-1930 [13 and 14]) were the exceptions. 


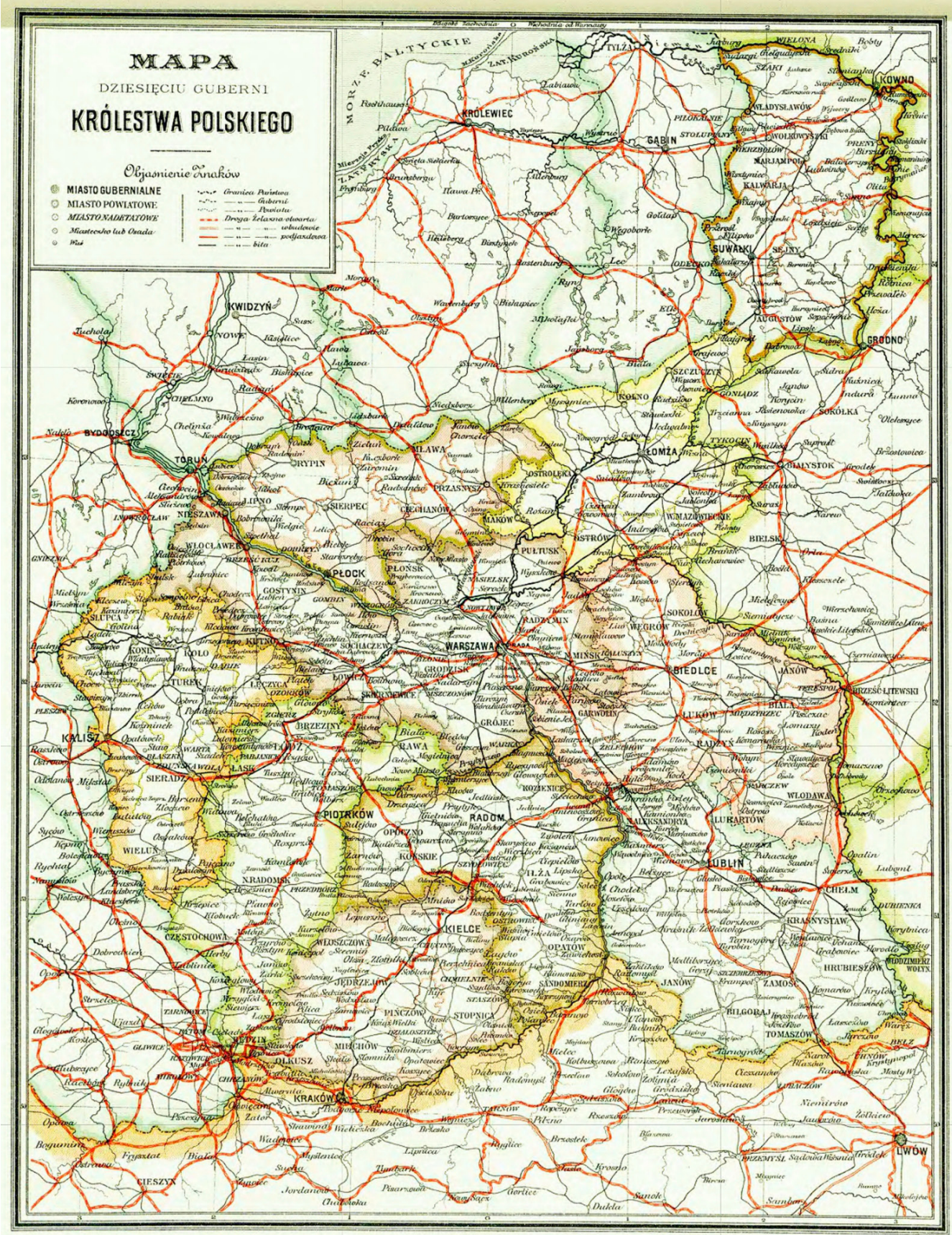

Fig. 4. The map of the Kingdom of Poland with the longitude indicated in relation to the Warsaw Meridian from the Podręczny atlas geograficzny (Geographical hand atlas) of the Orgelbrand Publishing House, about 
In the case of that second atlas, a continuous three-hundred-and-sixty-degree longitude record from the Greenwich Meridian was applied on one map of the world in the Mercator projection. It was interesting that there was a double notation up to $360^{\circ}$ west from Greenwich and from Ferro on the top frame of the map, and on the bottom frame - up to $360^{\circ}$ east from Greenwich. That record was probably intended to help to determine the angular distances between different places on the Earth relative to two standard meridians: for many people the meridian, which was previously used, was still the most famous, (i.e. the Ferro Meridian), and for other people, the meridian introduced as a new standard was a geographical novelty which had being assimilated so far (i.e. the Greenwich Meridian). After 1930, all the Polish school atlases contained the only longitude notation up to $180^{\circ}$ east and west from the Greenwich Meridian (fig. 5).

\section{Conclusions}

The evolution of the mathematical basis of maps in school atlases is an example of learning processes in teaching the latest trends and scientific arrangements that took place and occur between science and education. In the case of the Prime Meridian and a way of describing the geographical longitude on the maps, the turn of the 19th and 20th centuries was a special moment, when the arrangements of the International Meridional Conference began to enter into force. The signatories of that conference were the Austria-Hungary, Germany and Russia, which at that time occupied the Polish lands. The atlases appearing at that time reflected the tendencies prevailing in the school cartography of those three partitioning countries.

The breakthrough was the publication of the Atlas geograficzny (Geographical atlas) of E. Romer in 1908 [21], which initiated the modern Polish school cartography. In the interwar period, the Romer's cartography, also known as the Lvov or Polish cartographical school, was one of the most modern in the world. This is evidenced not only by the use of the notation of geographical coordinates according to the Greenwich Meridian, but also the selection of equal-area map projections and the use of multiple map scales, as well as the modern cartographic methods (including the hypsometric tints). At that time, on the Polish

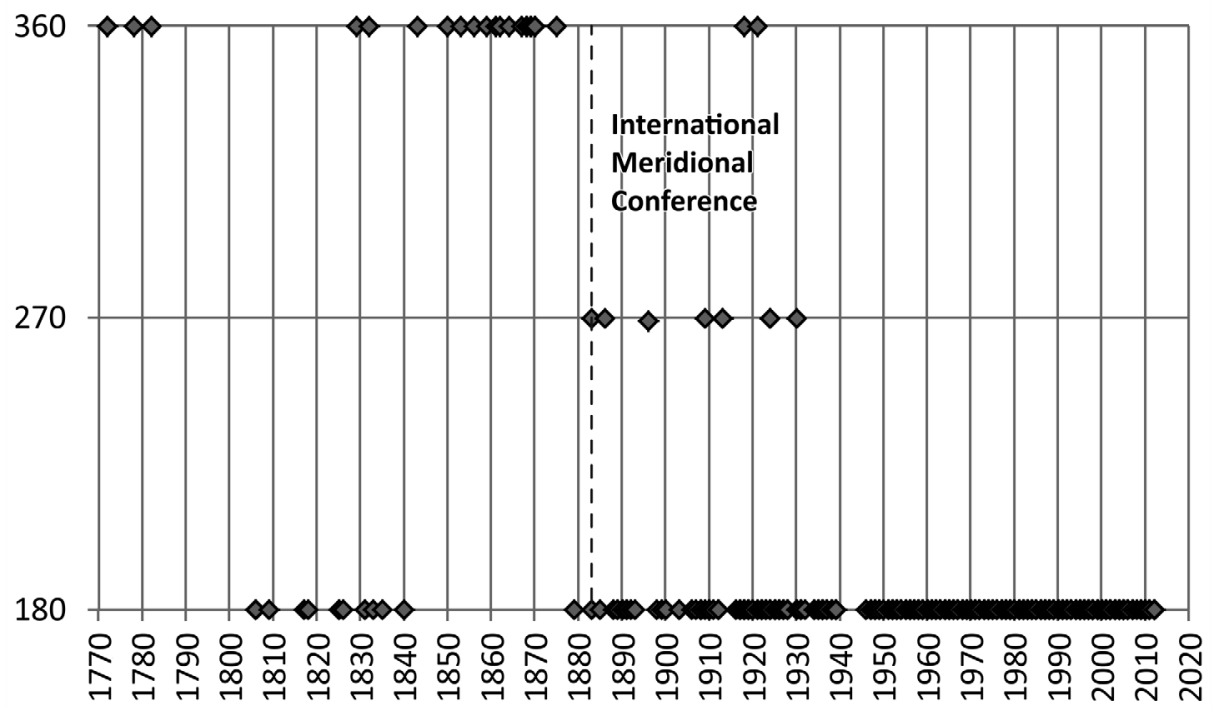

Fig. 5. The editions of the Polish school atlases according to the applied system of determining the longitude. $180^{\circ}+360^{\circ}$ category applies only to the W. Hardt's atlas for the folk schools (eight editions and circulations in the years of $1883-1930$ [13 and 14]) 


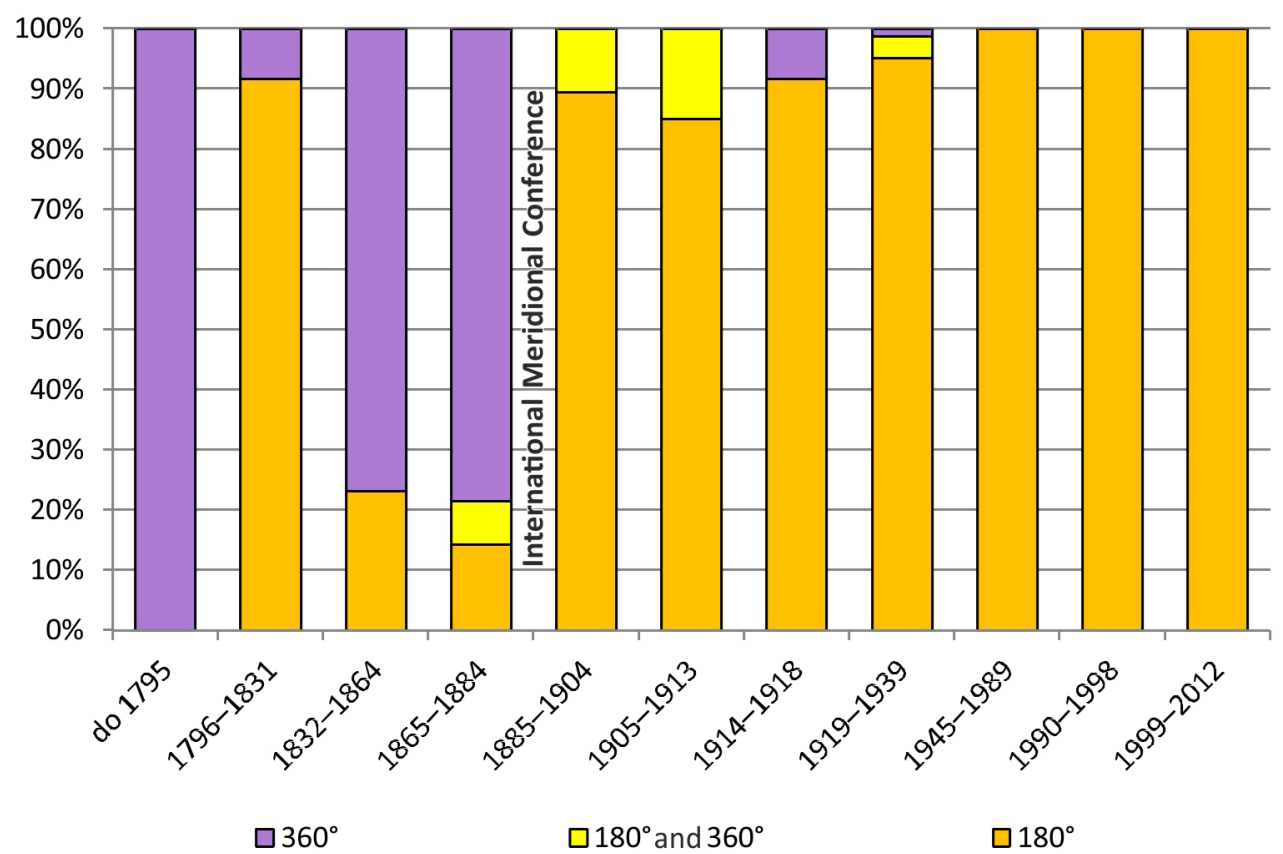

Fig. 6. The structure of atlases in the particular historical periods according to the applied system of determining the longitude. $180^{\circ}+360^{\circ}$ category applies only to the W. Hardt's atlas for the folk schools (eight editions and circulations in the years of 1883-1930 [13 and 14]) with the map of the world in the Mercator projection and the longitude notation from $0^{\circ}$ to $360^{\circ}$

school cartographical market in over a hundred editions of atlases just a few maps with the Ferro Meridian appeared, and only in one of them [25] it was used as the only one. After 1930, only the Greenwich Meridian and the description of the longitude $180^{\circ}$ east and west

\section{Literature}

International conference held at Washington for the purpose of fixing a prime meridian and a universal day. October, 1884. Protocols of the proceedings, 1884. Washington: Gibson Bros., Printers and Bookbinders.

Leszczyński A., 2015, Krwawa jatka Amerykanów. „Wyborcza. Ale historia. Tygodnik Historyczny”, nr 14 (168), pp. 8-10.

Monmonier M., 2004, Rhumb Lines and Map Wars. A Social History of the Mercator Projection. Chicago: University of Chicago Press.

Sirko M., 1999, Zarys historii kartografii. Lublin: Wydawnictwo Uniwersytetu Marii Curie-Skłodowskiej. from it were used in the Polish school geographical atlases. In some of the French atlases, such as Atlas Classique [23] from the same period, all the maps had the cartographical grids and the description of longitude according to the Paris Meridian.

Sobel D., 1998, W poszukiwaniu długości geograficznej. Prawdziwa historia samotnego geniusza, który rozwiązał największy problem swoich czasów. Poznań: Zysk i S-ka Wydawnictwo.

www.Greenwich, 2015, http://www.rmg.co.uk/explore/ astronomy-and-time/astronomy-facts/history/theprime-meridian-at-greenwich (access 2.02.2015).

www.Greenwich_meridian, 2015, http://www.thegreenwichmeridian.org/tgm/articles.php?article=10 (access 15.02.2015).

www.Paris, 2015, http://www.paris-walking-tours.com/ observatoryofparis.html\#top (access 2.02.2015). 


\section{Atlases}

[1] Atlas kieszonkowy z czternastu kart złożony z dokładnym tychże objaśnieniem, 1806. Wrocław: Wilhelm Bogumił Korn. Next edition about 1809 with title Atlas doręczny, złożony z kart czternastu, z których jedna stawia Księstwo Warszawskie.

[2] Atlas kieszonkowy z dwunastu kart złożony z dokładnym tychże objaśnieniem, 1806. Wrocław: Wilhelm Bogumił Korn. Next editions 1806 and 1826.

[3] Atlas mały kieszonkowy z siedmiu kart złożony. Do użycia przy jeografii Steina służyć mogący, 1817. Wrocław: Wilhelm Bogumił Korn. Next edition 1831 with title Powszechny doręczny atlas najnowszej jeografii złożony z 24 mapp.

[4] Atlas nowy jeografii dla użytku szkolnego, 1818. Wrocław: Wilhelm Bogumił Korn. Next editions 1825 and 1831.

[5] Atlas powszechny doręczny najnowszej jeografii, złożony z 24 map, 1825. Wrocław: Wilhelm Bogumił Korn.

[6] Bazewicz J. M., about 1918, Atlas geograficzny duży, szczegółowy wszystkich części świata. Warszawa: Author-publisher. Next edition 1921.

[7] Dzierżyński I., 1918, Atlas do geografji Polski. Cz. I. Przyroda. Warszawa: Author-publisher.

[8] Dzierżyński I., 1919, Atlas do geografji Polski. Cz. II. Ludność. Warszawa: Author-publisher.

[9] Gustawicz B., ok. 1908, Atlas geograficzny dla szkół ludowych i wydziałowych. Kraków: Author-publisher. Next edition 1910.

[10] Gustawicz B., ok. 1908, Atlas geograficzny dla szkół średnich. Kraków: Author-publisher. Next edition 1910.

[11] Gustawicz B., about 1910, Atlas geograficzny dla szkół ludowych i wydziałowych. Wiedeń: Zakład Kartograficzny G. Freytaga i Berndta. Next edition 1917.

[12] Gustawicz B., about 1917, Atlas geograficzny dla szkół średnich. Wiedeń: Zakład Kartograficzny G. Freytaga i Berndta. Next editions about 1919 and 1925 .
[13] Haardt W., 1883, Atlas geograficzny dla galicyjskich szkół ludowych. Wiedeń: Edward Hölzel. Next editions 1886, 1896, with title Atlas geograficzny dla szkół ludowych pospolitych i wydziałowych. Two editions after 1913, one edition in 1924 and one edition after 1924.

[14] Haardt W., Gustawicz B., 1930, Atlas geograficzny dla szkół średnich i powszechnych. Kraków: Księgarnia Powszechna.

[15] Kośmiński J., 1833, Atlas ieograficzny nowożytny $i$ starożytny przeznaczony dla użytku młodzieży. Warszawa: Author-publisher. Next edition 1835.

[16] Kośmiński J., about 1840, [Atlas geograficzny powszechny]. Warszawa: Author-publisher.

[17] Kozenn B., 1875, Mały atlas szkolny. Wiedeń: Edward Hölzel.

[18] Kozenn B., 1879, Atlas geograficzny dla szkół średnich i wydziałowych. Wiedeń: Edward Hölzel. So-called the first edition, with at least 11 impressions were issued till 1904.

[19] Kozenn B., Haardt W., Schmidt W., Gustawicz B., 1898, Atlas geograficzny dla szkół średnich (gimnazyalnych, realnych $i$ handlowych). Wiedeń: Edward Hölzel. Second edition.

[20] Podręczny atlas geograficzny, about 1908. Warszawa: Wydawnictwo Tow. Akc. S. Orgelbranda Synów.

[21] Romer E., 1908, Atlas geograficzny. Lwów, Warszawa: Towarzystwo Nauczycieli Szkół Wyższych, E. Wende i Ska.

[22] Schneider O., 1900, Atlas przyrodniczo-gieograficzny zawierający typy krajobrazów, ludzi, zwierząt i roślin. Warszawa: M. Arct.

[23] Schrader F., Gallouédec L., 1931, Atlas classique de Géographie ancienne et moderne. II Géographie moderne. Paris: Librairie Hachette. Nouvelle edition.

[24] Szybiński D., 1771, Atlas dziecinny czyli nowy sposób do nauczenia dzieci geografii krotki, łatwy, y naydoskonalszy... Warszawa: Michał Grel.

[25] Weinfeld I., Szturm de Sztrem E., Piekałkiewicz J., 1925, Szkolny atlas statystyczny Polski. Warszawa - Bydgoszcz: Biblioteka Polska. 